\title{
Application of Catalytic Wet Peroxide Oxidation for Industrial and Urban Wastewater Treatment: A Review
}

\author{
Juan José Rueda Márquez ${ }^{1, *}$, Irina Levchuk ${ }^{2}$ and Mika Sillanpää ${ }^{1}$ \\ 1 Laboratory of Green Chemistry, Lappeenranta University of Technology, Sammonkatu 12 (Innovation Centre \\ for Safety and Material Technology, TUMA), 50130 Mikkeli, Finland; mika.sillanpaa@lut.fi \\ 2 Water and Wastewater Engineering Research Group, School of Engineering, Aalto University, PO Box 15200, \\ FI-00076 Aalto, Finland; irina.levchuk@aalto.fi \\ * Correspondence: juan.rueda.marquez@lut.fi
}

Received: 12 November 2018; Accepted: 14 December 2018; Published: 19 December 2018

check for updates

\begin{abstract}
Catalytic wet peroxide oxidation (CWPO) is emerging as an advanced oxidation process (AOP) of significant promise, which is mainly due to its efficiency for the decomposition of recalcitrant organic compounds in industrial and urban wastewaters and relatively low operating costs. In current study, we have systemised and critically discussed the feasibility of CWPO for industrial and urban wastewater treatment. More specifically, types of catalysts the effect of $\mathrm{pH}$, temperature, and hydrogen peroxide concentrations on the efficiency of CWPO were taken into consideration. The operating and maintenance costs of CWPO applied to wastewater treatment and toxicity assessment were also discussed. Knowledge gaps were identified and summarised. The main conclusions of this work are: (i) catalyst leaching and deactivation is one of the main problematic issues; (ii) majority of studies were performed in semi-batch and batch reactors, while continuous fixed bed reactors were not extensively studied for treatment of real wastewaters; (iii) toxicity of wastewaters treated by CWPO is of key importance for possible application, however it was not studied thoroughly; and, (iv) CWPO can be regarded as economically viable for wastewater treatment, especially when conducted at ambient temperature and natural $\mathrm{pH}$ of wastewater.
\end{abstract}

Keywords: catalytic wet peroxide oxidation; heterogeneous Fenton; wastewater; cost; toxicity; iron leaching

\section{Introduction}

Water is a vital and limited resource, which is constantly under pressure from urbanisation, pollution, etc. The majority of these activities produce an over-exploitation of fresh water. For instance, at least $11 \%$ of the European population and $17 \%$ of its territory have been affected by water scarcity [1]. Even in highly developed countries, the majority of wastewater is discharged directly into the environment without adequate treatment, with detrimental impacts on human health, economic productivity, and the quality of freshwater resources and ecosystems [2]. In accordance with the Water Framework Directive [3], the good status of the water should have been achieved by 2015. However, only about half of European waters are able to meet the requirements of this directive [4].

Industrial and urban wastewater effluents have been recognised as one of the major sources of many environmental contaminants, such as polychlorinated biphenyls (PCBs) [5], polycyclic aromatic hydrocarbons (PAHs) [6], pharmaceutically active compounds (PhACs) [7], personal care products (PCPs) [7], pesticides [8], metals [9], antibiotics [10], and other pollutants of emerging concern. Neuroendocrine, mutagenic, and/or health effects on the aquatic environment when exposed to 
pollutants of emerging concern were reported [11]. Even at a low concentration $(\mu \mathrm{g} / \mathrm{L})$, some emerging contaminants (e.g. synthetic musks) are persistent and bio-accumulate due to their hydrophobicity [12], so an improvement of the existing wastewater treatment process is needed in order to prevent the spread of emerging pollutants into the environment.

Irrefutably, Advanced Oxidation Processes (AOPs) are promising methods for the degradation of resistant and recalcitrant compounds or their transformation into biodegradable form (partial mineralisation). It is generally accepted that during AOPs, the generation of highly reactive oxidising species, such as hydroxyl radicals, occurs. These oxidising species possess high electrochemical oxidation potential (standard oxidising potential for hydroxyl radicals varies between $2.8 \mathrm{~V}$ at $\mathrm{pH} 0$ and 2.0 at $\mathrm{pH} 14$ [13]) and a non-selective nature, leading to the degradation of organic contaminants, including those that are resistant to conventional oxidation processes, such as chlorination and ozonation [14]. When oxidising species react with organic pollutants in water, series of oxidation reactions are initiated causing, in an ideal case, complete mineralisation with the formation of $\mathrm{CO}_{2}$, water and inorganic ions as final products. After achieving the complete mineralisation of contaminants and the generated by-products, the further treatment of water is not needed [15]. This way, the secondary loading of contaminants into the environment can be avoided and AOPs can be considered as "clean technology" [15]. It is highly possible that AOPs can be among the most used water treatment processes for the elimination of persistent organic compounds from wastewater in the near future $[16,17]$. However, not all AOPs are feasible for the treatment of real wastewater due to high electricity demand, a significant amount of oxidant, the necessity of $\mathrm{pH}$ adjustment for optimal operation, etc. Among several AOPs that are studied and used for the purification of wastewater, catalytic wet peroxide oxidation (CWPO) or the heterogeneous Fenton process is emerging as one with significant promise (Figure 1).

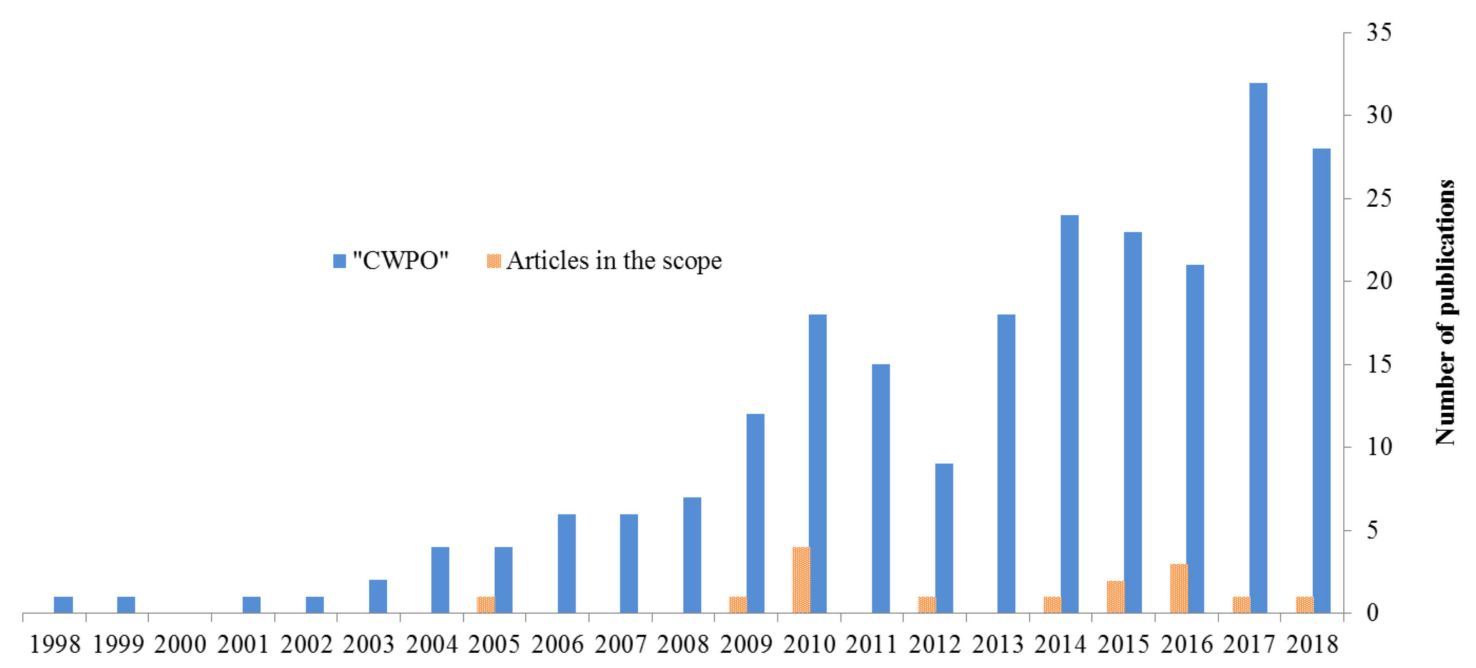

Figure 1. Number of scientific publications (Scopus) containing keywords: "CWPO" in the title and/or abstract and/or keywords of article (blue). Number of articles in the scope of the review (real wastewater matrix was used) in orange.

However, although the number of scientific publications is increasing, there are not many studies using real wastewaters (see Figure 1). The most common compounds that are used in CWPO tests are phenols and textile dyes [18-24] as model pollutants.

Taking into account that the composition of real industrial and municipal wastewaters is very complex, the matrix of wastewater may significantly affect the performance of CWPO in the removal of target pollutants. For instance, the removal efficiency of pharmaceuticals from industrial, urban, and hospital wastewater was reported to be lower than that from ultrapure water $[25,26]$, due to the possible complexation of inorganic ions, such as chloride, carbonate, sulphate, etc. with iron or their role as scavengers $[27,28]$. The aim of this article is to provide systematisation and critical 
discussion on the feasibility of CWPO for the treatment of industrial (textile, petrochemical, olive oil mill, pharmaceutical, cosmetic, winery, and coffee processing industries) and urban wastewaters. Hence, only research papers that are devoted to treatment of real and/or synthetic wastewaters (prepared based on a matrix of real wastewater) by CWPO were chosen for this review. Special attention was also devoted to toxicity assays when real wastewater was used, because of the important possible impact on the receiving environment.

\section{Main Principles and Mechanism of CWPO}

CWPO is considered to be a low-cost technology [28] because it can be operated without lamps (leading to reduction of electrical consumption) and at atmospheric temperature and pressure. The organic pollutants that are present in wastewater are degraded by hydroxyl radicals (HO) generated due to the partial decomposition of $\mathrm{H}_{2} \mathrm{O}_{2}$ promoted with an appropriate catalyst. Iron-based materials are the most commonly used catalysts for the CWPO process. Generally, catalysts are classified as supported and non-supported (Figure 2). Many studies focus on the development of new catalysts for CWPO in order to increase the stability of catalysts (avoiding iron leaching) and their efficiency in terms of organic compounds removal [29-32]. Some materials used in CWPO are synthesised using $\mathrm{Cu}^{2+}, \mathrm{Mn}^{2+}$, and $\mathrm{Co}^{2+}$.

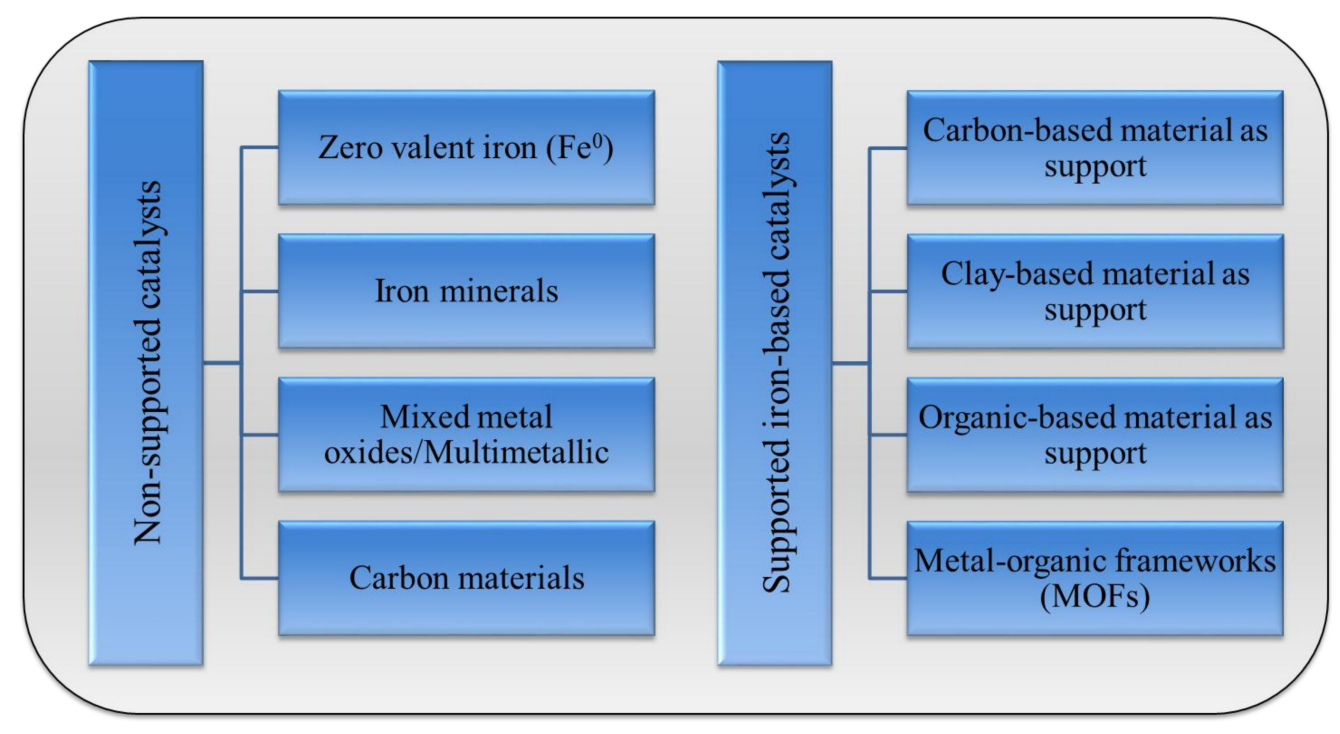

Figure 2. Classification of catalysts used for catalytic wet peroxide oxidation (CWPO).

In comparison with the widely studied homogeneous Fenton process, CWPO is especially attractive because it significantly reduces (e.g. zero valent iron) or does not generate sludge and it enables work in a wide $\mathrm{pH}$ range [33].

CWPO can be integrated into the water treatment process, as follows [34] (Figure 3):

(1) Increasing the quality of the industrial or urban wastewater effluent. In the final step of the wastewater treatment process, CWPO is able to remove residual contaminants, such as persistent toxic endocrine-disruption or refractory compounds, and to increase the quality of the treated effluent for water reuse or safe discharge.

(2) Increasing the biodegradability of industrial wastewater. In this case, CWPO can be applied before the biological process in order to increase the biodegradability of recalcitrant compounds and their suitability for biological treatment (conventional or not). It is important to mention that only non-biodegradable wastewaters are suitable for CWPO. The CWPO followed by biological processes can enhance the efficiency of the biological process and the viability of treatment from an economic point of view [35]. 
The concentration of organic contaminants (e.g. TOC or COD) in industrial wastewaters is significantly higher than that in urban effluents. Consequently, the operational conditions of CWPO applied for industrial wastewaters (prior biological treatment) and urban wastewater effluents (after biological treatment), such as temperature, catalyst load, and $\mathrm{H}_{2} \mathrm{O}_{2}$ consumption would significantly vary.

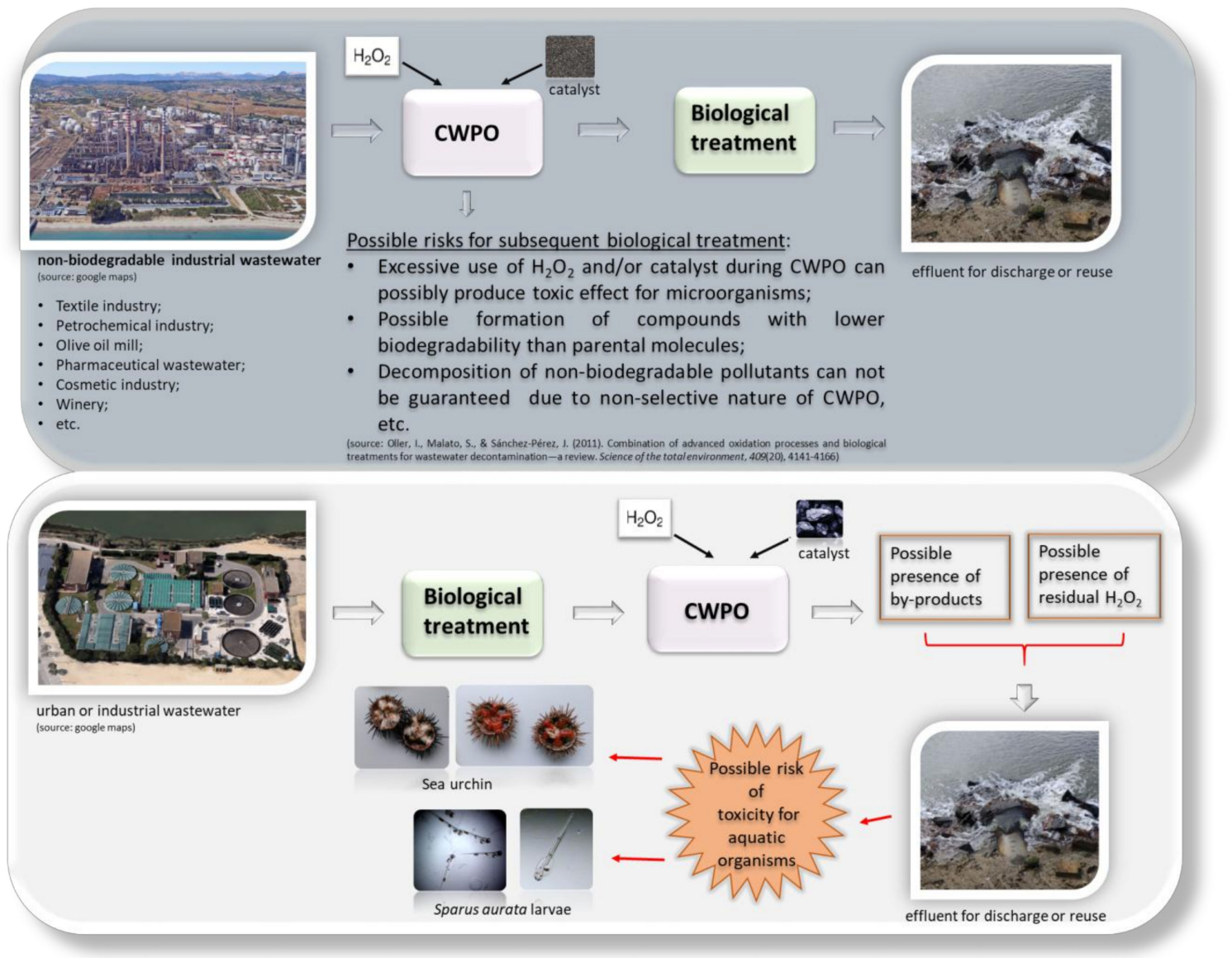

Figure 3. Schematic diagram showing possible integration of CWPO into the wastewater treatment process and potential risks.

It is generally accepted that the decomposition of organic contaminants during the CWPO process (heterogeneous Fenton) occurs mainly due to the presence of highly oxidative species, such as hydroxyl radicals $[13,36,37]$, which are formed during the classical Fenton's reaction.

$$
\begin{aligned}
& \mathrm{Fe}^{2+}+\mathrm{H}_{2} \mathrm{O}_{2} \rightarrow \mathrm{Fe}^{3+}+\mathrm{HO}+\mathrm{OH}^{-} \\
& \mathrm{Fe}^{3+}+\mathrm{H}_{2} \mathrm{O}_{2} \rightarrow \mathrm{Fe}^{2+}+\mathrm{HOO}+\mathrm{H}^{+}
\end{aligned}
$$

Iron-based catalysts that are usually used for CWPO possess a relatively low adsorption capacity towards organic compounds. The oxidation potential of hydrogen peroxide towards organic pollutants in wastewater is also known to be relatively weak, so the highly oxidative species that are generated as a result of complex reactions between hydrogen peroxide and iron-based catalysts play a crucial role in CWPO efficiency. Taking into consideration that different iron-based catalysts can be used for CWPO (e.g. zero valent iron, iron minerals, supported iron-based materials), the efficiency of the process will strongly depend on type of iron specie on the surface of catalyst [38]. For instance, the presence of $\mathrm{Fe}^{2+}$ on the surface of catalyst plays an important role in the formation of hydroxyl radicals (reaction 1). Leaching of $\mathrm{Fe}^{2+} / \mathrm{Fe}^{3+}$ into water during CWPO especially at low $\mathrm{pH}$ is another important factor, 
affecting the overall efficiency of the process. In a recent review [36], it was suggested that hydroxyl radicals, hydroperoxyl radicals, and high-valent iron species are among the main reactive oxygen species that are responsible for the decomposition of organic pollutants during CWPO. Generalised representation of the mechanism of CWPO catalysed by iron-based materials is shown in Figure 4A. However, the mechanism of CWPO catalysed by iron-based materials is not fully understood [36].

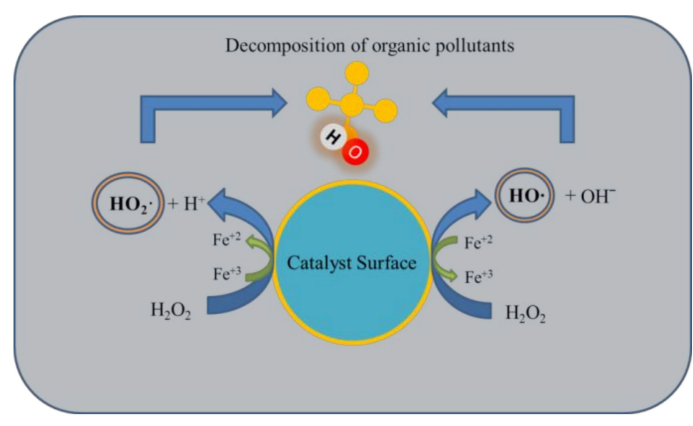

(A)

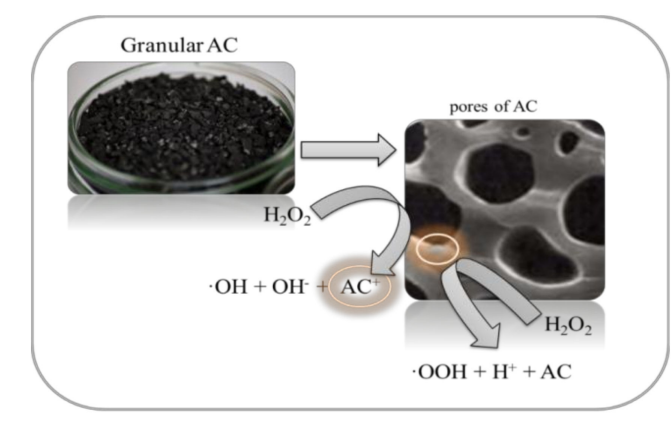

(B)

Figure 4. Schematic representation of CWPO mechanism A-catalysed by iron-based materials; B-catalysed by carbon materials (in the absence of iron).

The CWPO process catalysed by carbon-based materials (without iron) was reported to be efficient in the elimination of organic compounds in water (Figure 4B) [39-41]. According to recent studies, the generation of hydroxyl radicals occurs during the decomposition of hydrogen peroxide by carbon materials (reactions 3 and 4), as follows [39,42,43]:

$$
\begin{aligned}
& \mathrm{H}_{2} \mathrm{O}_{2}+\mathrm{AC} \rightarrow \mathrm{HO}+\mathrm{OH}^{-}+\mathrm{AC}^{+} \\
& \mathrm{AC}^{+}+\mathrm{H}_{2} \mathrm{O}_{2} \rightarrow \mathrm{AC}+\mathrm{HOO}+\mathrm{H}^{+}
\end{aligned}
$$

It was suggested that a predominant pathway of organic contaminant decomposition during CWPO occurs due to the attack of organic pollutants that are freely dissolved in the pore volume of activated carbon (AC) by hydroxyl radicals [44]. The adsorbed fraction of organic compounds was found to be almost non-reactive [44]. According to Anfruns et al. [45], the $\mathrm{H}_{2} \mathrm{O}_{2}$ treatment for the regeneration of activated carbon is limited for non-polar and hydrophobic compounds. Recently, the mechanism of this process was suggested $[13,46]$ to consist mainly of the following steps:

(1) reducing active sites on the surface of carbon materials promotes the decomposition of $\mathrm{H}_{2} \mathrm{O}_{2}$ and formation of $\mathrm{HO} \cdot[13,46]$;

(2) $\mathrm{H}_{2} \mathrm{O}_{2}$ adsorbed on oxidized active sites leads to the formation of $\mathrm{HOO} \cdot$ and $\mathrm{H}^{+}[13,46]$;

(3) adsorbed $\mathrm{HOO} \cdot$ and $\mathrm{H}^{+}$in contact with reducing active sites on the carbon surface can lead to the generation of atomic oxygen and water $[13,46]$;

(4) the reaction of $\mathrm{H}_{2} \mathrm{O}_{2}$ with formed $\mathrm{HOO} \cdot, \mathrm{HO} \cdot$, and $\mathrm{O}_{2}{ }^{--}$in the bulk can lead to the generation of $\mathrm{HOO} \cdot \mathrm{HO} \cdot \mathrm{O}_{2}$, and $\mathrm{H}_{2} \mathrm{O}[13,46]$

(5) $\mathrm{HOO} \cdot \mathrm{HO} \cdot$, and $\mathrm{O}_{2} \cdot{ }^{--}$radicals react with each other, leading to the formation of $\mathrm{H}_{2} \mathrm{O}, \mathrm{O}_{2}$, and low amounts of $\mathrm{H}_{2} \mathrm{O}_{2}[13,46]$.

\section{CWPO for the Enhancement of Industrial Wastewater Biodegradability}

About $50 \%$ of studies reviewed in this article were devoted to the application of CWPO to the enhancement of the biodegradability of industrial wastewater (textile, petrochemical, olive oil mill, pharmaceutical, cosmetic, winery, and coffee processing industries). The values of TOC and COD in the industrial wastewaters studied strongly varied. For instance, the COD of industrial wastewaters subjected to CWPO was in the range $0.3-58 \mathrm{~g} / \mathrm{L}$. In general, the biodegradability of the studied industrial wastewaters was poor, as indicated by a relatively low BOD/COD ratio (0.09-0.355). 
In more than half of the studies on the CWPO of industrial wastewater, the initial $\mathrm{pH}$ of wastewater was adjusted to 3-4. The results of CWPO applied to the enhancement of industrial wastewater biodegradability are summarised in Table 1 . It should be mentioned that wastewaters from textile dyeing, tannery, microelectronics, organic fertilizer production, dairy industries, etc. could be of particular interest for CWPO, and, to the best of our knowledge, remain missing.

\subsection{Catalysts}

In the majority of studies on the CWPO of industrial wastewaters, supported catalysts were used [47-52]. Mostly iron-based catalysts supported on silica [49,51], pillared clays (PILC) [47,48], and alumina [52] were applied, while copper-based catalyst supported on organic material [50] was also studied. To the best of our knowledge, non-supported catalyst (zero-valent iron) was only used for the treatment of industrial wastewater in one study [53]. This is not surprising, because supported catalysts are emerging as potential for CWPO, which is mainly due to the simplicity of catalyst separation after treatment and the fact that sludge is not generated.

The dose of catalyst that was used in studies on industrial wastewater treatment by CWPO varied from 0.5 to $5 \mathrm{~g} / \mathrm{L}$. Molina et al. [48] reported that iron loading $(\mathrm{Fe} /(\mathrm{Fe}+\mathrm{Al})$ molar ratios $0.05-0.15)$ is more important than catalyst concentration $(1.25-3.75 \mathrm{mg} / \mathrm{L})$, indicating the key importance to the iron loading for the efficiency of the process. Iron concentration in the catalyst was also reported to be more important than the surface area of the catalysts [54].

For the practical application of CWPO to real wastewater, the stability of catalyst and its efficiency in the long term are crucial. Interestingly, the stability of catalysts may vary in a real wastewater matrix and model solution. Thus, the stability of Al-Fe PILC catalyst during CWPO was higher in industrial wastewater than in an aqueous solution of 4-Chlorophenol [48]. To the best of our knowledge, only two studies evaluated long-term catalyst efficiency for the enhancement of industrial wastewater biodegradability [49,52]. Melero et al. [49] studied the stability of $\mathrm{Fe}_{2} \mathrm{O}_{3} / \mathrm{SBA}-15$ catalyst used in the treatment of industrial wastewater at a continuous up-flow fixed-bed reactor over a 55-hour period. A slight decrease in TOC removal and $\mathrm{H}_{2} \mathrm{O}_{2}$ consumption was observed after 20 hours of treatment. This observation was attributed to the possible modification of iron species during CWPO [55]. Despite this fact, the overall stability of the catalyst was high during the 55 hours of treatment, leading to $50-60 \%$ TOC elimination [49]. Interestingly, the leaching of iron was below $0.05 \mathrm{mg} / \mathrm{L}$ (detection limit of ICP-AES), suggesting the high stability of this catalyst [49]. Bautista et al. [52] demonstrated the high stability of $\mathrm{Fe} / \gamma-\mathrm{Al}_{2} \mathrm{O}_{3}$ catalyst for the treatment of cosmetic wastewater over 100 hours. An increase in $C$ and $S$ on the surface of the catalyst was observed after 100 hours, which was attributed to possible the adsorption or deposition of organic compounds on the surface. Interestingly, no significant effect of $\mathrm{C}$ and $\mathrm{S}$ deposits on the efficiency of the catalyst was observed. Moreover, the leaching of iron over 100 hours was below $3 \%$ of the initial iron weight [52].

The leaching of iron from catalysts after CWPO of industrial wastewater was studied in the majority of the reviewed articles. Generally, the leaching of iron from catalysts increases as the $\mathrm{pH}$ decreases. For example, the concentration of dissolved iron from $\mathrm{Fe}^{0}$ decreased from 13.8 to $0.39 \mathrm{mg} / \mathrm{L}$ with an increase of $\mathrm{pH}$ from 2 to 8 [53]. Moreover, with increase of iron concentration in the catalyst, the dissolution of iron (leaching) rises, but not proportionally [48]. The effect of the initial TOC concentration of wastewater on the leaching of iron from silica-supported iron oxide catalyst $\left(\mathrm{Fe}_{2} \mathrm{O}_{3} /\right.$ SBA-15) was studied by Pariente et al. [51]. It was demonstrated that, as the initial TOC of petrochemical wastewater increases, so does the leaching of iron from the catalyst.

A correlation between the percentage of eliminated TOC and amount of leached iron was reported [48]. This was attributed to the generation of by-products during CWPO, such as oxalic acid, which may significantly increase the leaching of iron from the catalyst due to possible iron complexation [56]. Pariente et al. [51] reported a decrease in iron leaching from the catalyst with an increase in temperature from 120 to $160^{\circ} \mathrm{C}$. This was explained by the fact that, at higher temperature, 
the decomposition of low molecular weight carboxylic acids (for instance, oxalic acid) is more efficient than that at a lower temperature.

\subsection{Temperature}

Temperature is an important factor to be taken into account during CWPO. In reviewed studies that are devoted to the enhancement of industrial wastewater biodegradability through the application of CWPO, the employed temperature of the process varied from 25 to $160{ }^{\circ} \mathrm{C}$. Interestingly, CWPO of industrial wastewater was conducted at an ambient temperature only in two studies [50,53], while, in majority of the studies, the temperature was higher than $50^{\circ} \mathrm{C}$ [47-49,51,52]. An increase in reaction temperature might significantly enhance the decomposition of organic pollutants from wastewaters and the consumption of $\mathrm{H}_{2} \mathrm{O}_{2}$. COD removal from olive mill wastewater increased from 37 to $69 \%$ as the process temperature was raised from 25 to $70{ }^{\circ} \mathrm{C}$ [47]. The elimination of COD and TOC from cosmetic wastewater was significantly enhanced when the temperature of CWPO was elevated from 50 to $70{ }^{\circ} \mathrm{C}$, while a further increase of temperature up to $85^{\circ} \mathrm{C}$ did not result in a significant increase in organic pollutants removal [52]. Interestingly, the removal of TOC of petrochemical wastewater that was treated by CWPO at a temperature of $120-160^{\circ} \mathrm{C}$ did not vary significantly with a change in temperature [51]. One should keep in mind that, as the temperature of the process increases, so does the cost of the treatment. Hence, optimization of operational conditions, such as the temperature of CWPO, is of high importance for practical application.

\subsection{Effect of Initial Concentration of Organic Pollutants in Wastewater}

When working in water treatment, one should keep in mind fluctuations in pollutants concentration, which can significantly affect the efficiency of the applied process. Domínguez et al. [54] studied the effect of initial organic loading (COD 3.5, 17 and $35 \mathrm{~g} / \mathrm{L}$ ) of winery wastewater on the efficiency of CWPO. Interestingly, it was demonstrated that the effect of the initial concentration of organic pollutants on the efficiency of CWPO is insignificant when a stoichiometric amount of $\mathrm{H}_{2} \mathrm{O}_{2}$ is added in accordance with the initial organic load [54].

The effect of the initial TOC $(0.22-2.2 \mathrm{~g} / \mathrm{L})$ of petrochemical wastewater on the performance of intensified CWPO was studied [51]. A notable increase in TOC elimination was reported with a decrease in the initial TOC of the wastewater. However, it was suggested that the optimization of operating conditions for more concentrated wastewaters would allow the application of intensified CWPO.

\subsection{Effect of $\mathrm{pH}$}

CWPO can be operated in a wide $\mathrm{pH}$ range, but the efficiency of CWPO can significantly vary at different pHs. For instance, the degradation of model compound (benzoic acid) by $\mathrm{Fe}_{3} \mathrm{O}_{4} @ \mathrm{CeO}_{2}$ was studied in a wide pH range (3.2-10.3) [57]. About $80 \%$ of model compound removal was achieved at acidic and neutral $\mathrm{pH}$, while in alkaline conditions the performance of CWPO significantly decreased (below 50\%). The wastewater's $\mathrm{pH}$ affects not only the performance of the process, but also the mechanism (homogeneous or heterogeneous Fenton) that is involved during CWPO catalysed by iron-based materials. Usually, a higher performance of CWPO catalysed by iron-based materials is obtained at $\mathrm{pH} 3-4$. For instance, the elimination of COD from industrial wastewater (coal-chemical engineering wastewater effluent) during the CWPO $\left(\mathrm{Fe}^{0} / \mathrm{H}_{2} \mathrm{O}_{2}\right)$ process increased up to $98 \%$ with a decrease of $\mathrm{pH}$ from 8 to 3 [53]. Often, at $\mathrm{pH}$ below 3, the reaction slows down. It was demonstrated that, at acidic and neutral $\mathrm{pH}$, the consumption of hydrogen peroxide during the CWPO of industrial wastewater is very similar, while the elimination of organic pollutants is higher in acidic conditions [54]. This can be explained by the fact that different a mechanism occurs at acidic and neutral/alkaline $\mathrm{pH}$. At $\mathrm{pH}$ above 4, some hydrogen peroxide decomposes into water and oxygen [58]. In the $\mathrm{pH}$ range of 3-4, more iron dissolves from the catalyst (in the case of an iron-based catalyst), leading to the occurrence of the homogenous Fenton process in parallel with heterogeneous Fenton. The occurrence 
of a homogeneous Fenton reaction during CWPO is not always desirable, as it may decrease the operating time of the catalyst in the long-term perspective. In more than $70 \%$ of research papers on the CWPO of industrial wastewater reviewed in this article, the initial $\mathrm{pH}$ of the wastewater varied between 2.8 and 4 . In some cases, the natural $\mathrm{pH}$ of wastewater was in this range, while, in majority of the studies, wastewater was acidified in order to improve the efficiency of CWPO. It should be mentioned that $\mathrm{pH}$ adjustment (decrease before and increase after treatment) of industrial wastewater prior to CWPO could significantly increase the cost of the treatment when applied on an industrial scale.

\subsection{Effect of $\mathrm{H}_{2} \mathrm{O}_{2}$ Concentration}

The initial concentration of $\mathrm{H}_{2} \mathrm{O}_{2}$ added to wastewater prior to the CWPO treatment of industrial wastewaters varied from $100 \mathrm{mg} / \mathrm{L}$ to $17.8 \mathrm{~g} / \mathrm{L}$ (in reviewed articles). Such variation can be explained by the different initial loading of organic pollutants in wastewater. In the majority of reviewed articles, a stoichiometric ratio of $\mathrm{H}_{2} \mathrm{O}_{2}$ 0.5-2 times the concentration of unknown contaminants (like TOC or COD) was used. Pliego et al. [59] reported that the stoichiometric amount of $\mathrm{H}_{2} \mathrm{O}_{2}$ required for the complete mineralization of COD in real wastewaters is $2.125 \mathrm{~g}$ per $\mathrm{g}$ of COD. Generally, the removal of organic pollutants from wastewaters by CWPO increases with a rise of added $\mathrm{H}_{2} \mathrm{O}_{2}$ concentration up to a certain level. However, when the concentration of added $\mathrm{H}_{2} \mathrm{O}_{2}$ is too high, the opposite effect is often reported [53]. This phenomenon can possibly be explained by the fact that an excessive amount of $\mathrm{H}_{2} \mathrm{O}_{2}$ plays the role of a hydroxyl radical scavenger, as shown in reactions 5 and 6 [60].

$$
\begin{gathered}
\mathrm{H}_{2} \mathrm{O}_{2}+\mathrm{HO}^{\circ} \rightarrow \mathrm{H}_{2} \mathrm{O}+\mathrm{HO}_{2} \\
\mathrm{HO}_{2}+\mathrm{HO}^{-} \rightarrow \mathrm{H}_{2}+\mathrm{O}_{2}
\end{gathered}
$$

The addition of hydrogen peroxide to the process can be conducted in two ways: (a) the single addition of $\mathrm{H}_{2} \mathrm{O}_{2}$ at the beginning of the process and (b) the gradual addition of $\mathrm{H}_{2} \mathrm{O}_{2}$. The gradual addition of $\mathrm{H}_{2} \mathrm{O}_{2}$ was reported to be more efficient than the addition of all the $\mathrm{H}_{2} \mathrm{O}_{2}$ at the beginning of CWPO, leading to the higher removal of organic pollutants from industrial wastewater and the almost full consumption of $\mathrm{H}_{2} \mathrm{O}_{2}$ during the treatment [54,61].

The effect of initial $\mathrm{H}_{2} \mathrm{O}_{2}$ concentration on the elimination of COD, TOC, and the toxicity (Photobacterium phosphoreum) of winery wastewater by CWPO $\left(125^{\circ} \mathrm{C}\right.$, graphite $\left.5 \mathrm{~g} / \mathrm{L}, \mathrm{pH} 3.8\right)$ was studied [54]. The increase of initial $\mathrm{H}_{2} \mathrm{O}_{2}$ concentration in wastewater led to an increase in COD and TOC removal (up to $\mathrm{H}_{2} \mathrm{O}_{2}$ /COD 1.6 stoichiometric), but when the dose of the initial $\mathrm{H}_{2} \mathrm{O}_{2}$ was between 0 and 0.5 times stoichiometric, the treated wastewater was relatively toxic. Interestingly, with a further increase of the initial $\mathrm{H}_{2} \mathrm{O}_{2}$ dose ( 1 and 1.6 times the stoichiometric amount), the toxicity of the wastewater after treatment significantly decreased, indicating that the toxic by-products were decomposed [54]. Thus, the optimum dose of $\mathrm{H}_{2} \mathrm{O}_{2}$ for elimination of toxicity was about stoichiometric.

\subsection{Toxicity}

To the best of our knowledge, a toxicity assessment of industrial wastewater that was treated by CWPO was carried out in only two studies [47,54]. Acute toxicity bioassays of Vibrio fischeri [47] and Photobacterium phosphoreum [54] were used. Interestingly, in some cases, the effluent of industrial wastewater after CWPO was significantly more toxic than raw wastewater, which can be attributed to the generation of by-products with higher toxicity than parent pollutants [54]. However, with an increase in reaction temperature, the toxicity of the final effluent decreased, indicating the decomposition of toxic by-products [54]. An increase in toxicity during CWPO was observed during the first two hours of the CWPO of industrial wastewater, followed by a decrease in toxicity with an increase in treatment time [47]. It should be mentioned that, in both studies, residual hydrogen peroxide was removed from the wastewater before toxicity assessment, so the possible synergetic effect of hydrogen peroxide and formed by-products was not evaluated. 


\subsection{Cost Estimation}

Considering all of the advantages of CWPO for the pre-treatment (prior biological process) of non-biodegradable industrial wastewater, its practical application on an industrial scale might be beneficial. In order to evaluate the possibility of introducing CWPO on an industrial scale, cost estimation should be taken into account. Among the scientific articles devoted to the treatment of industrial wastewater by CWPO (reviewed in this study), a preliminary cost assessment was done only in one study [53]. The operating cost of CWPO $\left(\mathrm{Fe}^{0} / \mathrm{H}_{2} \mathrm{O}_{2}, 25^{\circ} \mathrm{C}\right)$, followed by the aerobic biological treatment of coal-chemical engineering wastewater, was estimated to be $0.35 \$ / \mathrm{m}^{3}$ [53]. It should be mentioned that a relatively low operating cost was achieved mostly by avoiding the adjustment of wastewater $\mathrm{pH}$ (initial $\mathrm{pH}$ 6.8) and conducting CWPO at an ambient temperature. When considering that the majority of the studies devoted to application of CWPO as pre-treatment step were conducted at elevated temperatures and with preliminary $\mathrm{pH}$ adjustment, the main operational costs in this case would be (1) energy cost for conducting CWPO at high temperatures, (2) acidification of wastewater, (3) $\mathrm{H}_{2} \mathrm{O}_{2}$, and (4) cost of catalyst. Sulfuric acid is usually used for adjustment of wastewater $\mathrm{pH}$. The price of this reagent is about $0.25 € / \mathrm{kg}$ [62]. Taking into account that the $\mathrm{pH}$ of wastewater treated by CWPO is usually close to neutral, the decrease of wastewater $\mathrm{pH}$ can be associated with a relatively high cost on the industrial scale. Moreover, the cost of possible water neutralization (usually conducted using $\mathrm{NaOH}, 0.55 € / \mathrm{kg}$ ) after $\mathrm{CWPO}$ is not taken into account.

The initial organic load in wastewaters prior to biological treatment is usually relatively high; therefore, the dose of hydrogen peroxide that is required for CWPO is also high. In some cases, CWPO as a pre-treatment step for wastewater cannot be economically feasible due to the high cost of hydrogen peroxide. We have estimated the cost of $\mathrm{H}_{2} \mathrm{O}_{2}$ as a function of the initial concentration of organic compounds in wastewater (Figure $5 \mathrm{~A}$ ), while considering that the price of $\mathrm{H}_{2} \mathrm{O}_{2}$ is $0.45 € / \mathrm{L}[63,64]$. Different catalysts can be used for CWPO; hence, the cost can vary significantly.

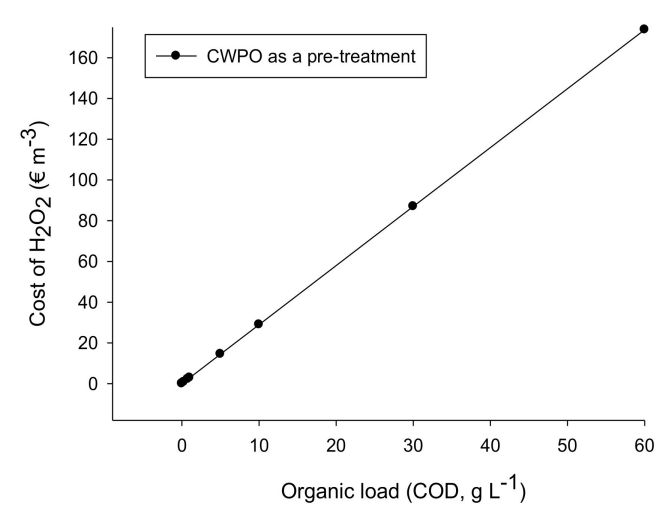

(A)

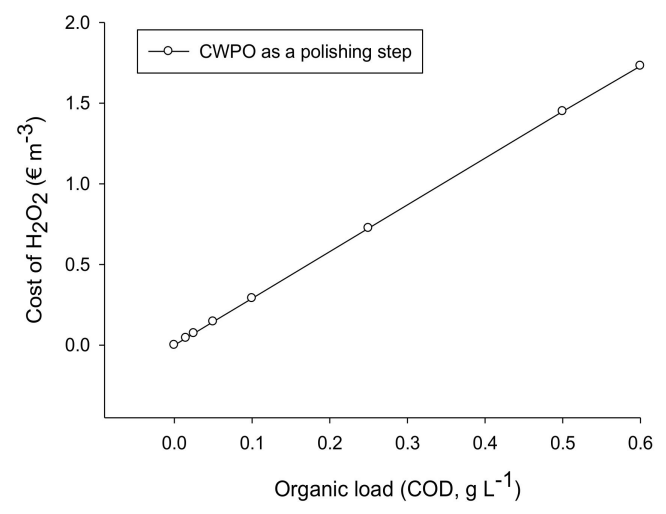

(B)

Figure 5. Cost of the $\mathrm{H}_{2} \mathrm{O}_{2}$ reagent as a function of the initial wastewater TOC (when stoichiometric amount of $\mathrm{H}_{2} \mathrm{O}_{2}$ is added) for CWPO as pre-treatment (A) and as a post-treatment (B).

\section{CWPO as a Post-treatment Step for Urban and Industrial Wastewater Effluents}

In the majority of studies that are devoted to the application of CWPO as a post-treatment step (after the biological process), synthetic and real industrial wastewater effluents were used. To the best of our knowledge, only in one study were urban wastewater effluent and hospital wastewater treated by CWPO [26]. The initial COD and TOC values (when measured) for synthetic and real industrial wastewater effluents that were treated by CWPO varied from 25 to $551 \mathrm{mg} / \mathrm{L}$ (COD) and from 15 to $27 \mathrm{mg} / \mathrm{L}$ (TOC), respectively. The TOC levels of urban wastewater effluent and hospital wastewater that were treated by CWPO were $2.6 \mathrm{mg} / \mathrm{L}$ and $110 \mathrm{mg} / \mathrm{L}$, respectively [26]. The main outcomes of the studies where CWPO was applied as a post-treatment step are summarised in Table 2. 


\subsection{Catalysts}

Iron-based catalysts that were supported on pillared clays [65] and alumina [26] were used as catalysts for the post-treatment of wastewater effluents by CWPO. The dose of iron-based supported catalysts varied from 2 to $5 \mathrm{~g} / \mathrm{L}$. However, granular activated carbon (GAC) without supported metals (such as iron, copper, etc.) was applied as a catalyst for the CWPO of real and synthetic industrial wastewater effluents in more than $60 \%$ of the studies focused on CWPO as the post-treatment method. For CWPO with carbon materials, a column of GAC was used (140.1 $\mathrm{g}$ of GAC). It is not surprising that carbon materials were used in the majority of the studies devoted to the post-treatment of wastewater effluents by CWPO, as they are highly beneficial for practical application due to the following properties [13]:

- High stability in wide temperature range;

- Stability under different $\mathrm{pH}$ conditions;

- High surface area;

- No leaching;

- Efficient for decomposition of $\mathrm{H}_{2} \mathrm{O}_{2}$; and,

- Low cost.

Moreover, depending on the source of carbon materials, they may contain metals, such as iron and copper, as impurities, which might affect the efficiency of CWPO. CWPO with carbon materials as catalyst is especially efficient as a post-treatment step when applied after Fenton/photo-Fenton and /or $\mathrm{UV} / \mathrm{H}_{2} \mathrm{O}_{2}$ processes due to the high efficiency of $\mathrm{H}_{2} \mathrm{O}_{2}$ elimination and the removal of possibly toxic pollutants [42]. Therefore, CWPO with GAC as catalysts were efficient in the decrease of the initial TOC and COD of industrial wastewater effluent (previously treated by $\mathrm{UV} / \mathrm{H}_{2} \mathrm{O}_{2}$ process) from 27 to $16.7 \mathrm{mg} / \mathrm{L}$ and from 59 to $26.6 \mathrm{mg} / \mathrm{L}$, respectively, only after five minutes of contact time with GAC [66]. It should be noted that residual $\mathrm{H}_{2} \mathrm{O}_{2}$ after the $\mathrm{UV} / \mathrm{H}_{2} \mathrm{O}_{2}$ process was sufficient for CWPO. When the initial load of organic pollutants in wastewater effluent is lower, even shorter contact time can be sufficient for the significant elimination of pollutants. For instance, already after $2.3 \mathrm{~min}$ of CWPO, the TOC of industrial wastewater effluent decreased from 15 to $3.75 \mathrm{mg} / \mathrm{L}$, while COD decreased from 35 to $14.9 \mathrm{mg} / \mathrm{L}$ [43].

Interestingly, about $50 \%$ of the mineralisation (initial COD $551 \mathrm{mg} / \mathrm{L}$ ) of biologically treated industrial wastewater was achieved after five hours of treatment with the Al-Ce-Fe-PILC catalyst [65]. The efficiency of CWPO with iron-based catalyst in the decomposition of widely used pharmaceuticals from hospital and urban wastewater effluents was recently demonstrated [26].

\subsection{Temperature and $p H$}

All studies that were devoted to the post-treatment of industrial wastewater effluents by CWPO reviewed in this article were conducted at an ambient temperature $\left(20-25^{\circ} \mathrm{C}\right)$. Only one study focusing on the elimination of pharmaceuticals from hospital and urban wastewater by CWPO was performed at a higher temperature $\left(75^{\circ} \mathrm{C}\right)[26]$.

When carbon materials were used as catalysts for the CWPO post-treatment of industrial wastewater effluents, the experiments were conducted without adjustment of wastewater $\mathrm{pH}$. However, when iron-based catalysts were used, the $\mathrm{pH}$ of wastewaters was adjusted to 3-4.

\section{3. $\mathrm{H}_{2} \mathrm{O}_{2}$ Concentration and Toxicity}

The initial concentration of $\mathrm{H}_{2} \mathrm{O}_{2}$ used for CWPO applied as post-treatment step for industrial and urban wastewater effluents (in reviewed papers) varied between $79.3 \mathrm{mg} / \mathrm{L}$ and $3.4 \mathrm{~g} / \mathrm{L}$. It should be mentioned that the high efficiency of $\mathrm{H}_{2} \mathrm{O}_{2}$ consumption is one of the main advantages of CWPO [49], so, after the post-treatment of industrial wastewater effluents by CWPO using GAC, full consumption of $\mathrm{H}_{2} \mathrm{O}_{2}$ was reported [42,43,66,67]. Interestingly, very short contact time (between 2.3 and 6 min) 
was sufficient for the significant elimination of organic pollutants and complete decomposition of $\mathrm{H}_{2} \mathrm{O}_{2}[42,43,66,67]$. Complete consumption of hydrogen peroxide during CWPO is extremely beneficial from a practical point of view due to the absence of residual hydrogen peroxide in wastewater effluent, so the possible toxicity of the final effluent (when CWPO is applied as post-treatment step) might be avoided. Interestingly, relatively high concentrations of residual $\mathrm{H}_{2} \mathrm{O}_{2}$ (about $70 \mathrm{mg} / \mathrm{L}$ ) were reported after the treatment of urban and hospital wastewater effluents spiked with environmentally representative concentrations of pharmaceuticals ( $\mu \mathrm{g} / \mathrm{L})$ [26]. It should be noted that the presence of hydrogen peroxide, even at low concentrations in discharged effluent, could be toxic for aquatic organisms in receiving water bodies [68]. It is therefore very important to ensure complete $\mathrm{H}_{2} \mathrm{O}_{2}$ consumption during CWPO when it is applied as a post-treatment step.

Assessment of the toxicity of industrial wastewater effluents after CWPO was performed using acute toxicity bioassays with Vibrio fischeri [67], Sparus aurata [43], and Paracentrotus lividus (fertilisation and embryo-larval development) [42]. It is worth noting that $\mathrm{H}_{2} \mathrm{O}_{2}$ was not removed from the wastewater prior to toxicity assessment in any of the reviewed studies that were devoted to CWPO post-treatment of wastewater, so the synergetic effect of pollutants and $\mathrm{H}_{2} \mathrm{O}_{2}$ in wastewaters was estimated. To the best of our knowledge, no toxicity assessment of urban wastewater effluents that were treated by CWPO has yet been reported. Generally, after CWPO, the toxicity of wastewater effluent decreases. For instance, Rueda-Márquez et al. [67] reported that the toxicity of refinery wastewater effluent after CWPO decreased enormously according to the most sensitive tested species (EC 50 , P. lividus embryo-larval development). Based on a toxicity assessment of industrial wastewater effluents that were treated with CWPO, the effluents were recommended for safe discharge [42,43,67]. As far as authors are aware, there were no reports of toxicity assessments during the CWPO of real wastewater effluent when applied as a post-treatment step. Despite the fact that $\mathrm{H}_{2} \mathrm{O}_{2}$ is considered an environmental-friendly agent $[7,69]$, the presence of $\mathrm{H}_{2} \mathrm{O}_{2}$ at high concentration in discharged wastewater effluents can be highly toxic for the aquatic environment $[42,43,68]$.

\subsection{Cost Estimation}

Preliminary estimation of the operating and maintenance costs of CWPO that were applied to the post-treatment of wastewater effluents included only the cost of the catalyst and $\mathrm{H}_{2} \mathrm{O}_{2}$ reagent. Since the CWPO process was conducted at ambient temperature and at the natural $\mathrm{pH}$ of wastewater effluents, additional costs related to heating and/or $\mathrm{pH}$ adjustment were eliminated. The cost of the catalyst (GAC) was estimated to be 0.042 and $0.028 € / \mathrm{m}^{3}$ (including the cost of regeneration) [70,71]. Generally, the concentration of organic carbon in wastewater effluents was relatively low $(15-27 \mathrm{mg} / \mathrm{L}$ of TOC). The occurrence of the oxidation process (CWPO) on the GAC surface prevented the saturation of the activated carbon, and so it caused a decrease in the regeneration cost (about $90 \%$ of the total cost). Therefore, the cost of the catalyst (GAC) was estimated to be $0.0035 € / \mathrm{m}^{3}$ (without regeneration cost). However, if the organic load of the wastewater is significantly higher (TOC $>3 \mathrm{~g} / \mathrm{L}$ ), the deposition of some reaction products on the surface of $\mathrm{AC}$ can occur [72], leading to the necessity of $\mathrm{AC}$ regeneration.

The concentration of $\mathrm{H}_{2} \mathrm{O}_{2}$ used during CWPO depends on organic load of the wastewater. Generally, when CWPO is applied as a post-treatment process, lower concentrations of $\mathrm{H}_{2} \mathrm{O}_{2}$ are used in comparison with CWPO that is applied as pre-treatment process. Taking into account that that the cost of $\mathrm{H}_{2} \mathrm{O}_{2}$ reagent is $0.45 € / \mathrm{L}[63,64]$, the cost of $\mathrm{H}_{2} \mathrm{O}_{2}$ that is used during CWPO can be estimated to be $0.10-4.63 € / \mathrm{m}^{3}$ (see Figure $5 \mathrm{~B}$ ). From this estimation, it can be seen that when the required concentration of $\mathrm{H}_{2} \mathrm{O}_{2}$ is relatively high, CWPO is not economically viable. In the case of wastewater effluents, the concentration of $\mathrm{H}_{2} \mathrm{O}_{2}$ required for decomposition of organic pollutants that are present in water can be estimated according to [59], so an approximation of the $\mathrm{H}_{2} \mathrm{O}_{2}$ cost depending on the initial load of organic pollutants in wastewater can be made (Figure 5B). Thus, the total cost of CWPO catalysed by carbon materials applied as a post-treatment method for wastewater effluents (at ambient temperature and the natural $\mathrm{pH}$ of wastewater) can be estimated at $0.11-0.22 € / \mathrm{m}^{3}[42,43,67]$. 
Table 1. CWPO for Increasing Biodegradability of Industrial Wastewater.

\begin{tabular}{|c|c|c|c|c|}
\hline Reference & Type of Catalyst & Type of the Wastewater & Experimental Conditions & Main Outcomes \\
\hline [52] & $\begin{array}{l}\mathrm{Fe} / \gamma-\mathrm{Al}_{2} \mathrm{O}_{3} \\
\text { (in form of powder) }\end{array}$ & $\begin{array}{l}\text { Wastewater from cosmetic industry (TOC } \\
691 \mathrm{mg} / \mathrm{L} \text { and COD } 2376 \mathrm{mg} / \mathrm{L} \text { ) }\end{array}$ & $\begin{array}{l}\text { Operating conditions: } \mathrm{pH} 3,50-85^{\circ} \mathrm{C} \text {, concentration } \\
\text { of catalyst } 2,500-5,000 \mathrm{mg} / \mathrm{L} \text {, concentration of } \mathrm{H}_{2} \mathrm{O}_{2} \\
2,272-9,088 \mathrm{mg} / \mathrm{L}\end{array}$ & $\begin{array}{c}\text { About } 80 \% \text { of COD was eliminated at } 85{ }^{\circ} \mathrm{C}, \mathrm{H}_{2} \mathrm{O}_{2} 2272 \mathrm{mg} / \mathrm{L} \text { and } \\
\text { space-time of } 9.4 \mathrm{~kg} \text { cath } / \mathrm{kgCOD} \text {. The } \mathrm{H}_{2} \mathrm{O}_{2} \text { was fully consumed. Stability } \\
\text { of catalyst during } 100 \mathrm{~h} \text { was demonstrated. Leaching of Fe from catalyst } \\
\text { was lower than } 3 \% \text {. }\end{array}$ \\
\hline [51] & $\begin{array}{l}\mathrm{Fe}_{2} \mathrm{O}_{3} / \mathrm{SBA}-15 \\
\text { (silica supported) }\end{array}$ & $\begin{array}{l}\text { Diluted wastewater from petrochemical } \\
\text { industry (TOC } 0.22-2.2 \mathrm{~g} / \mathrm{L} \text { ) }\end{array}$ & $\begin{array}{l}\text { Operating conditions: } 5 \mathrm{~g} \text { of catalyst was used in } \\
\text { fixed-bed reactor, } 120-160^{\circ} \mathrm{C}, 7,14 \text { and } 21 \mathrm{~g} \text { of } \\
\qquad \mathrm{H}_{2} \mathrm{O}_{2} / \mathrm{g} \text { of } \mathrm{TOC}\left(\text { at } 160^{\circ} \mathrm{C}\right)\end{array}$ & $\begin{array}{l}\text { Removal of TOC was not affected by increase in temperature. As the } \\
\text { temperature increased, the leaching of iron decreased. An increase of } \\
\mathrm{H}_{2} \mathrm{O}_{2} \text { concentration enhanced TOC removal }\left(\mathrm{at} 160^{\circ} \mathrm{C}\right) \text {. Optimal } \\
\text { conditions were } 160^{\circ} \mathrm{C} \text { and } 14 \mathrm{~g} \text { of } \mathrm{H}_{2} \mathrm{O}_{2} / \mathrm{g} \text { of TOC. }\end{array}$ \\
\hline [53] & $\mathrm{Fe} 0$ (powder) & $\begin{array}{l}\text { Coal-chemical engineering wastewater } \\
\text { effluent (COD } 341 \pm 6 \mathrm{mg} / \mathrm{L} \text { ) }\end{array}$ & $\begin{array}{l}\text { Operating conditions: } \mathrm{Fe} 00.1-4 \mathrm{~g} / \mathrm{L}, \mathrm{pH} 2-8, \mathrm{H}_{2} \mathrm{O}_{2} \\
5-50 \mathrm{mmol} / \mathrm{L}, 25^{\circ} \mathrm{C}\end{array}$ & $\begin{array}{l}\text { In optimal operational conditions }\left(\mathrm{pH} 6.8, \mathrm{Fe} 02 \mathrm{~g} / \mathrm{L}, \mathrm{H}_{2} \mathrm{O}_{2} 25 \mathrm{mmol} / \mathrm{L} \text { ) }\right. \\
66 \% \text { of COD removal was achieved. }\end{array}$ \\
\hline [47] & Al-Fe-PILC & Olive mill wastewater (COD $12.5 \mathrm{~g} / \mathrm{L}$ ) & $\begin{array}{l}\text { Operating conditions: } 25,50 \text { and } 70^{\circ} \mathrm{C} \text {, atmospheric } \\
\text { pressure, Al-Fe-PILC } 0.5 \mathrm{~g} / \mathrm{L}, \mathrm{H}_{2} \mathrm{O}_{2} 2 \cdot 10-2 \mathrm{M}, \mathrm{pH} 5.2 \\
\text { (natural for WW) }\end{array}$ & $\begin{array}{c}\text { In optimal operational conditions }\left(50^{\circ} \mathrm{C}, 8 \mathrm{~h} \text { ) about } 50 \% \text { of initial COD }\right. \\
\text { was eliminated. Moreover, toxicity of water (bioluminescent test with } \\
\text { Vibrio Vischeri) decreased by } 70 \% \text {. }\end{array}$ \\
\hline [48] & Al-Fe-PILC & $\begin{array}{l}\text { Wastewater from cosmetic factory (COD } \\
4200 \mathrm{mg} / \mathrm{L} \text {, for the majority of experiments } \\
\text { it was diluted } 10 \text { times) }\end{array}$ & $\begin{array}{c}\text { Operating conditions: } 90^{\circ} \mathrm{C}, \mathrm{Fe} \text { load }(\mathrm{Fe} /(\mathrm{Fe}+\mathrm{Al}) \\
\text { molar ratio) } 0.05-0.15 \text {, catalyst } 1250-3750 \mathrm{mg} / \mathrm{L}, \\
\mathrm{H}_{2} \mathrm{O}_{2} / \mathrm{COD} \text { ratios } 0.5-2 \text { stoichiometric doses }(2.12 \mathrm{~g} \\
\left.\mathrm{H}_{2} \mathrm{O}_{2} / \mathrm{g} \text { COD }\right)\end{array}$ & $\begin{array}{l}\text { Highest levels of COD removal (about } 70 \% \text { ) from wastewater were } \\
\text { achieved at highest Fe loading and catalyst dose. With increase of } \\
\mathrm{H}_{2} \mathrm{O}_{2} / \mathrm{COD} \text { ratio, the elimination of COD increased. }\end{array}$ \\
\hline [49] & $\begin{array}{l}\mathrm{Fe}_{2} \mathrm{O}_{3} / \mathrm{SBA}-15 \\
\text { nanocomposite } \\
\text { (fixed bed) }\end{array}$ & $\begin{array}{l}\text { Pharmaceutical wastewater (COD } 1901 \mathrm{mg} \\
\text { O2/L, TOC } 860 \mathrm{mg} / \mathrm{L} \text { ) }\end{array}$ & $\begin{array}{l}\text { Operating conditions: } 60,80 \text { and } 100{ }^{\circ} \mathrm{C}, \mathrm{pH} 3 \text { and } 5.6, \\
\mathrm{H}_{2} \mathrm{O}_{2} / \mathrm{C} \text { mass ratio } 7\left(5400 \mathrm{mg} / \mathrm{L} \text { of } \mathrm{H}_{2} \mathrm{O}_{2}\right) \\
\text { and } 14\left(10800 \mathrm{mg} / \mathrm{L} \text { of } \mathrm{H}_{2} \mathrm{O}_{2}\right), 2.9 \mathrm{~g} \text { of catalyst }\end{array}$ & $\begin{array}{l}\text { Optimal operating conditions at continuous up-flow fixed bed reactor } \\
\text { were } \mathrm{pH} 3 \text {, initial } \mathrm{H}_{2} \mathrm{O}_{2} \text { concentration } 10,800 \mathrm{mg} / \mathrm{L} \text {, feed flow rate } \\
0.25 \mathrm{~mL} / \mathrm{min}, 80^{\circ} \mathrm{C} \text {, amount of catalyst } 2.9 \mathrm{~g} \text {. Decrease of COD and TOC } \\
\text { at optimal conditions was } 81 \% \text { and } 59 \% \text {, respectively. }\end{array}$ \\
\hline [54] & $\begin{array}{l}\text { graphite, activated } \\
\text { carbon, carbon black }\end{array}$ & $\begin{array}{c}\text { Winery wastewater }(\mathrm{COD} 35 \pm 2.5 \mathrm{~g} / \mathrm{L} \\
\text { TOC } 11.3 \pm 0.9 \mathrm{~g} / \mathrm{L})\end{array}$ & $\begin{array}{l}\text { Operating conditions: } 80,100,125^{\circ} \mathrm{C}, \mathrm{pH} 2.2-7, \mathrm{H}_{2} \mathrm{O}_{2} \\
\text { doses } 0-1.6 \text { stoichiometric amount related to } \mathrm{COD} \text {. }\end{array}$ & $\begin{array}{l}\text { About } 80 \% \text { of } \mathrm{COD} \text { elimination and a significant decrease in wastewater } \\
\text { toxicity (Photobacterium phosphoreum) was obtained using } 5 \mathrm{~g} / \mathrm{L} \text { of graphite } \\
\text { at natural pH of the wastewater }(3.8), 125^{\circ} \mathrm{C} \text { and stoichiometric amount of } \\
\qquad \mathrm{H}_{2} \mathrm{O}_{2} \text { (added stepwise). }\end{array}$ \\
\hline [50] & $\begin{array}{c}\mathrm{Cu}_{3}(\mathrm{BTC})_{2}\left(\mathrm{H}_{2} \mathrm{O}\right)_{3} \\
\text { BTC-benzene } \\
\text { 1,3,5-tricarboxylic acid }\end{array}$ & Olive oil mill wastewater (COD $57.7 \mathrm{~g} / \mathrm{L}$ ) & $\begin{array}{l}\text { Operating conditions: catalyst dose } 0.97 \mathrm{~g} / \mathrm{L}, \mathrm{H}_{2} \mathrm{O}_{2} \\
113.2 \mathrm{mg} / \mathrm{L} \text {, max temperature } 32.85^{\circ} \mathrm{C}\end{array}$ & $\begin{array}{l}\text { About } 96 \% \text { of polyphenol present in wastewater was removed after CWPO. } \\
\text { Biodegradability of wastewater significantly increased after treatment. }\end{array}$ \\
\hline
\end{tabular}


Table 2. Catalytic wet peroxide oxidation (CWPO) as a post-treatment.

\begin{tabular}{|c|c|c|c|c|}
\hline Reference & Type of catalyst & Type of the Wastewater & Experimental Conditions & Main Outcomes \\
\hline [67] & $\begin{array}{l}\text { GAC (supported } \\
\text { in column) }\end{array}$ & $\begin{array}{l}\text { Refinery wastewater effluent after } \\
\mathrm{H}_{2} \mathrm{O}_{2} / \text { UVC. Two different influents: } \\
\text { 1) TOC: } 17 \mathrm{mg} / \mathrm{L}, \text { COD } 20 \mathrm{mg} / \mathrm{L} \text { and } 2) \\
\text { TOC: } 19 \mathrm{mg} / \mathrm{L}, \text { COD } 15 \mathrm{mg} / \mathrm{L} \text {. }\end{array}$ & $\begin{array}{l}\text { Two experiments in ambient conditions }\left(20 \pm 2^{\circ} \mathrm{C}\right) \\
\text { were passing through } \mathrm{GAC}(141.1 \mathrm{~g} / \mathrm{L}) \text {. Initial } \\
\text { concentrations of } \mathrm{H}_{2} \mathrm{O}_{2} \text { during CWPO were } \\
\text { 1) } 160 \mathrm{mg} / \mathrm{L} \text { and 2) } 96 \mathrm{mg} / \mathrm{L} \text {. }\end{array}$ & $\begin{array}{l}\text { The } \mathrm{H}_{2} \mathrm{O}_{2} \text { concentration after CWPO treatments was not detected (in either } \\
\text { experiment). The concentrations of TOC and COD were 1) } 1.75 \text { and } 9 \mathrm{mg} / \mathrm{L} \\
\text { and 2) } 3.5 \text { and } 6.4 \mathrm{mg} / \mathrm{L} \text {, respectively. The contact time for CWPO was } 6 \text { and } \\
3.5 \mathrm{~min} \text { for experiments } 1 \text { ) and 2). Toxicity evaluation of influent and effluent } \\
\text { of CWPO was evaluated using P. lividus embryo larvae and fertilisation tests. } \\
\text { The toxicity of the water after treatment decreased more than } 220 \text { times and } \\
\text { reduced the Toxic Units from IV to } 0 .\end{array}$ \\
\hline [43] & $\begin{array}{l}\text { GAC (supported } \\
\text { in column) }\end{array}$ & $\begin{array}{l}\text { Simulated industrial wastewater effluent in } \\
\text { urban wastewater matrix after } \mathrm{H}_{2} \mathrm{O}_{2} / \mathrm{UVC} \\
\text { (TOC } 15 \mathrm{mg} / \mathrm{L} \text { and COD } 35.4 \mathrm{mg} / \mathrm{L} \text { ) }\end{array}$ & $\begin{array}{c}\text { The effluent }(0.5 \mathrm{~L}) \text { of photo-Fenton in ambient } \\
\text { conditions }\left(20^{\circ} \mathrm{C}\right) \text { was passing through } \mathrm{AC} \text { column } \\
(141.1 \mathrm{~g} / \mathrm{L}) \text {. Initial concentration of } \mathrm{H}_{2} \mathrm{O}_{2} \text { was } \\
79.3 \mathrm{mg} / \mathrm{L} \text {. }\end{array}$ & $\begin{array}{l}\text { TOC, COD and } \mathrm{H}_{2} \mathrm{O}_{2} \text { were sufficiently removed by } 57,76.6 \text { and } 100 \% \text {, } \\
\text { respectively after } 2.3 \text { min of contact time. The final effluent was recommended } \\
\text { for safe discharge in marine water bodies after toxicity evaluation using } \\
\text { Sparus aurata larvae and Vibrio fischeri. }\end{array}$ \\
\hline [66] & $\begin{array}{l}\text { GAC (supported } \\
\text { in column) }\end{array}$ & $\begin{array}{l}\text { Plywood mill effluent (diluted } 10 \text { times) } \\
\text { after } \mathrm{H}_{2} \mathrm{O}_{2} / \text { UVC treatment }(\mathrm{TOC} 27 \mathrm{mg} / \mathrm{L} \\
\text { and COD } 59.6 \mathrm{mg} / \mathrm{L})\end{array}$ & $\begin{array}{c}\text { The effluent of } \mathrm{H}_{2} \mathrm{O}_{2} / \mathrm{UVC} \text { in ambient conditions } \\
\left(20 \pm 2^{\circ} \mathrm{C}\right) \text { was passing through } \mathrm{GAC}(141.1 \mathrm{~g} / \mathrm{L}) \text {. } \\
\text { Initial concentration of } \mathrm{H}_{2} \mathrm{O}_{2} \text { was } 100 \mathrm{mg} / \mathrm{L} \text { and pH } \\
6.0 \text {. }\end{array}$ & $\begin{array}{l}\text { TOC, } \mathrm{COD} \text { and } \mathrm{H}_{2} \mathrm{O}_{2} \text { were sufficiently removed by } 56,39 \text { and } 100 \% \text {, } \\
\text { respectively after } 5 \text { min of contact time. The pH of the water after treatment } \\
\text { was } 8.0 \text {. }\end{array}$ \\
\hline [42] & $\begin{array}{l}\text { GAC (supported in } \\
\text { column) }\end{array}$ & $\begin{array}{l}\text { Simulated industrial wastewater effluent in } \\
\text { urban wastewater matrix after } \mathrm{H}_{2} \mathrm{O}_{2} / \mathrm{UVC} \\
\text { (TOC } 21 \mathrm{mg} / \mathrm{L} \text { and COD } 39 \mathrm{mg} / \mathrm{L} \text { ) }\end{array}$ & $\begin{array}{c}\text { The effluent of } \mathrm{H}_{2} \mathrm{O}_{2} / \mathrm{UVC} \text { int ambient conditions } \\
\text { was passing through } \mathrm{GAC} \text { column }(141.1 \mathrm{~g} / \mathrm{L}) \text {. Initial } \\
\text { concentration of } \mathrm{H}_{2} \mathrm{O}_{2} \text { was } 161 \mathrm{mg} / \mathrm{L} \text {. The pH of the } \\
\text { water was 7.4. }\end{array}$ & $\begin{array}{l}\text { Concentration of TOC, COD and } \mathrm{H}_{2} \mathrm{O}_{2} \text { after } 3.5 \text { min of contact time were } 4.2 \text {, } \\
16.4 \text { and }<\text { D.L, respectively. The } \mathrm{pH} \text { of the water after the experiment was 7.9. } \\
\text { The toxicity of the final effluent was evaluated using V. fischeri and P. lividus } \\
\text { (embryo larvae development and fertilisation test). The most sensitive test, } \\
\text { embryo larvae development, demonstrated that the water decreased in toxicity } \\
\text { after CWPO by around } 350 \text { times (based on EC50). }\end{array}$ \\
\hline [65] & $\begin{array}{l}\text { Al-Ce-Fe-PILC } \\
\text { (pillared } \\
\text { inter-layered clays) }\end{array}$ & $\begin{array}{l}\text { Coffee wet processing wastewater after } \\
\text { biological treatment (COD } 551 \mathrm{mg} \mathrm{O}_{2} / \mathrm{L} \text { ) }\end{array}$ & $\begin{array}{l}\text { Operational conditions: } 25^{\circ} \mathrm{C} \text {, Al-Ce-Fe-PILC } 5 \mathrm{~g} / \mathrm{L} \\
\qquad \mathrm{H}_{2} \mathrm{O}_{2} 0.1 \mathrm{M}, \mathrm{pH} \text { adjusted to } 3.7\end{array}$ & $\begin{array}{l}\text { After CWPO of wastewater (5h) 50\% of mineralisation, } 70 \% \text { of phenolic } \\
\text { compound conversion. }\end{array}$ \\
\hline [26] & $\mathrm{Fe} 3 \mathrm{O} 4 / \gamma-\mathrm{Al} 2 \mathrm{O} 3$ & $\begin{array}{c}\text { Hospital wastewater (COD } 365 \mathrm{mg} / \mathrm{L} \text {, TOC } \\
110 \mathrm{mg} / \mathrm{L} \text { [73] and MWW effluent } \\
\text { (TOC 2.6 mg/L) spiked with six } \\
\text { pharmaceuticals }\end{array}$ & $\begin{array}{l}\text { Operational conditions: } 75^{\circ} \mathrm{C} \text {, catalyst dose } 2 \mathrm{~g} / \mathrm{L}, \mathrm{pH} \\
3, \mathrm{H}_{2} \mathrm{O}_{2} 730 \mathrm{mg} / \mathrm{L} \text { or } 100 \mathrm{mg} / \mathrm{L}(\text { when concentration } \\
\text { of spiked pharmaceuticals was } 10 \mu \mathrm{g} / \mathrm{L} \text { of each) }\end{array}$ & $\begin{array}{l}\text { Complete elimination of spiked pharmaceuticals (at high concentrations) from } \\
\text { hospital wastewater and urban wastewater effluent was achieved after } 90 \text { min } \\
\left(\mathrm{H}_{2} \mathrm{O}_{2} 730 \mathrm{mg} / \mathrm{L}\right) \text {. When pharmaceuticals were spiked at lower concentrations, } \\
\text { complete degradation was reached after } 30 \mathrm{~min}\left(\mathrm{H}_{2} \mathrm{O}_{2} 100 \mathrm{mg} / \mathrm{L}\right) \text {. }\end{array}$ \\
\hline
\end{tabular}




\section{Conclusions, Knowledge Gaps, and Future Perspectives}

This study discusses the feasibility of catalytic wet peroxide oxidation (CWPO) for pre-treatment (before biological treatment) and post-treatment (after the biological process) of industrial and urban wastewaters. Based on the reviewed literature, it can be suggested that CWPO is feasible as both a pre-treatment and post-treatment step for industrial and urban wastewaters. Interestingly, CWPO can be regarded as economically viable when performed at an ambient temperature and at the natural $\mathrm{pH}$ of the wastewater. For instance, the reported cost of CWPO as a pre-treatment step was $0.35 € / \mathrm{m}^{3}$ and $0.11-0.22 € / \mathrm{m}^{3}$ when CWPO is applied to post-treatment. The knowledge gaps and future perspectives that were identified in this study are presented below:

- Metal leaching and deactivation (e.g. due to mechanical and thermal degradation, poisoning, fouling, etc.) are among the main drawbacks of iron-based catalysts for practical application of CWPO. Based on revised literature it can be suggested that carbon materials are among the most promising catalysts for the practical application of CWPO for wastewater treatment. Properties of carbon materials, such as stability in a wide range of $\mathrm{pH}$ and temperature, high surface area, absence of leaching, possibility to control some surface properties, and relatively low cost of catalysts [74], makes them especially attractive for application.

- It can be expected that the elimination of emerging pollutants and the decrease of toxicity of municipal wastewater effluents by CWPO can be very efficient. However, there is a lack of studies that are devoted to the application of CWPO as post-treatment for municipal wastewater effluents.

- To the best of our knowledge, there is a lack of data on the toxicity assessment of wastewater during the CWPO process. Moreover, in all studies dealing with CWPO for the treatment of wastewater, only acute toxicity bioassays were used.

- Cost estimation is very important to the evaluation of CWPO feasibility for wastewater treatment. Cost assessment was reported in only a few studies (some reviewed in this work). Interestingly, cost evaluation was reported only when CWPO was conducted at an ambient temperature and the natural $\mathrm{pH}$ of wastewater.

- Despite the fact that CWPO was shown to be a promising treatment method, majority of studies with industrial or urban wastewaters were conducted at the laboratory scale. Moreover, among the revised studies, mostly batch or semi-batch reactors were used, while continuous catalytic systems, such as fixed bed reactors, were less studied. Taking into account that fixed bed reactors are promising from the practical point of view (especially for recovery and reuse of catalyst) and the reaction mechanism in batch and fixed bed reactors may vary due to different ratio between catalyst and water [75], it can be expected that in the future these will be more studied. Catalysts with magnetic properties can also be of high interest for the practical application of CWPO for wastewater treatment, which is mainly due to the simplicity of catalyst separation after treatment. However, investigations that are focused on industrial wastewater treatment by CWPO catalysed by magnetic catalysts are lacking.

Author Contributions: J.R., I.L. and M.S. did the literature search, elaborate discussion and wrote the paper. Conflicts of Interest: The authors declare no conflict of interest.

\section{References}

1. European Commission. Water Scarcity \& Droughts in the European Union; European Commission: Brussels, Belgium, 2016.

2. WWAP. The United Nations World Water Development Report 2017. Wastewater: The Untapped Resource; UNESCO: Paris, France, 2017.

3. European Commission. Directive 2000/60/EC; European Commission: Brussels, Belgium, 2000. 
4. Ec-European Commission. A Blueprint to Safeguard Europe's Water Resources, Communication from the Commission to the European Parliament, the Council, the European Economic and Social Committee and the Committee of the Regions; Ec-European Commission: Brussels, Belgium, 2012.

5. Jing, R.; Fusi, S.; Chan, A.; Capozzi, S.; Kjellerup, B.V. Distribution of polychlorinated biphenyls in effluent from a large municipal wastewater treatment plant: Potential for bioremediation? J. Environ. Sci. 2018. [CrossRef]

6. Qiao, M.; Bai, Y.; Cao, W.; Huo, Y.; Zhao, X.; Liu, D.; Li, Z. Impact of secondary effluent from wastewater treatment plants on urban rivers: Polycyclic aromatic hydrocarbons and derivatives. Chemosphere 2018, 211, 185-191. [CrossRef] [PubMed]

7. Lara-Martín, P.A.; González-Mazo, E.; Petrovic, M.; Barceló, D.; Brownawell, B.J. Occurrence, distribution and partitioning of nonionic surfactants and pharmaceuticals in the urbanised Long Island Sound Estuary (NY). Mar. Pollut. Bull. 2014, 85, 710-719. [CrossRef] [PubMed]

8. Pintado-Herrera, M.G.; González-Mazo, E.; Lara-Martín, P.A. Atmospheric pressure gas chromatography-time-of-flight-mass spectrometry (APGC-ToF-MS) for the determination of regulated and emerging contaminants in aqueous samples after stir bar sorptive extraction (SBSE). Anal. Chim. Acta 2014, 851, 1-13. [CrossRef] [PubMed]

9. Fu, F.; Wang, Q. Removal of heavy metal ions from wastewaters: A review. J. Environ. Manag. 2011, 92, 407-418. [CrossRef] [PubMed]

10. Thai, P.K.; Ky, L.X.; Binh, V.N.; Nhung, P.H.; Nhan, P.T.; Hieu, N.Q.; Dang, N.T.T.; Tam, N.K.B.; Anh, N.T.K. Occurrence of antibiotic residues and antibiotic-resistant bacteria in effluents of pharmaceutical manufacturers and other sources around Hanoi. Vietnam. Sci. Total Environ. 2018, 645, 393-400. [CrossRef] [PubMed]

11. François, G.; Mélanie, D.; Marlène, F.; Michel, F. Effects of a municipal effluent on the freshwater mussel Elliptio complanata following challenge with Vibrio anguillarum. J. Environ. Sci. 2015, 37, 91-99. [CrossRef]

12. Deblonde, T.; Hartemann, P. Environmental impact of medical prescriptions: Assessing the risks and hazards of persistence, bioaccumulation and toxicity of pharmaceuticals. Public Health 2013, 127, 312-317. [CrossRef]

13. Ribeiro, R.S.; Silva, A.M.T.; Figueiredo, J.L.; Faria, J.L.; Gomes, H.T. Catalytic wet peroxide oxidation: A route towards the application of hybrid magnetic carbon nanocomposites for the degradation of organic pollutants. A review. Appl. Catal. B Environ. 2016, 187, 428-460. [CrossRef]

14. Tchobanoglous, G.; Burton, F.L.; Stensel, H.D. Wastewater Engineering. Treatment and Reuse; McGraw-Hill Higher Education: Singapore, 2004.

15. Ribeiro, A.R.; Nunes, O.C.; Pereira, M.F.R.; Silva, A.M.T. An overview on the advanced oxidation processes applied for the treatment of water pollutants defined in the recently launched Directive 2013/39/EU. Environ. Int. 2015, 75, 33-51. [CrossRef]

16. Gogate, P.R.; Pandit, A.B. A review of imperative technologies for wastewater treatment I: Oxidation technologies at ambient conditions. Adv. Environ. Res. 2004, 8, 501-551. [CrossRef]

17. Gogate, P.R.; Pandit, A.B. A review of imperative technologies for wastewater treatment II: Hybrid methods. Adv. Environ. Res. 2004, 8, 553-597. [CrossRef]

18. Diaz de Tuesta, J.L.; Quintanilla, A.; Casas, J.A.; Rodriguez, J.J. P-, B- and N-doped carbon black for the catalytic wet peroxide oxidation of phenol: Activity, stability and kinetic studies. Catal. Commun. 2017, 102, 131-135. [CrossRef]

19. Munoz, M.; de Pedro, Z.M.; Casas, J.A.; Rodriguez, J.J. Combining efficiently catalytic hydrodechlorination and wet peroxide oxidation (HDC-CWPO) for the abatement of organochlorinated water pollutants. Appl. Catal. B Environ. 2014, 150, 197-203. [CrossRef]

20. Munoz, M.; de Pedro, Z.M.; Casas, J.A.; Rodriguez, J.J. Improved wet peroxide oxidation strategies for the treatment of chlorophenols. Chem. Eng. J. 2013, 228, 646-654. [CrossRef]

21. Rashwan, W.E.; Fathy, N.A.; Elkhouly, S.M. A novel catalyst of ceria-nanorods loaded on carbon xerogel for catalytic wet oxidation of methyl green dye. J. Taiwan Inst. Chem. Eng. 2018, 88, 234-242. [CrossRef]

22. Rodrigues, C.S.D.; Carabineiro, S.A.C.; Maldonado-Hódar, F.J.; Madeira, L.M. Wet peroxide oxidation of dye-containing wastewaters using nanosised Au supported on Al2O3. Catal. Today 2017, 280, 165-175. [CrossRef]

23. Tehrani-Bagha, A.R.; Gharagozlou, M.; Emami, F. Catalytic wet peroxide oxidation of a reactive dye by magnetic copper ferrite nanoparticles. J. Environ. Chem. Eng. 2016, 4, 1530-1536. [CrossRef] 
24. Ribeiro, R.S.; Silva, A.M.T.; Figueiredo, J.L.; Faria, J.L.; Gomes, H.T. The role of cobalt in bimetallic iron-cobalt magnetic carbon xerogels developed for catalytic wet peroxide oxidation. Catal. Today 2017, 296, 66-75. [CrossRef]

25. Cheng, M.; Zeng, G.; Huang, D.; Lai, C.; Liu, Y.; Zhang, C.; Wan, J.; Hu, L.; Zhou, C.; Xiong, W. Efficient degradation of sulfamethazine in simulated and real wastewater at slightly basic $\mathrm{pH}$ values using Co-SAM-SCS $/ \mathrm{H}_{2} \mathrm{O}_{2}$ Fenton-like system. Water Res. 2018, 138, 7-18. [CrossRef]

26. Munoz, M.; Mora, F.J.; de Pedro, Z.M.; Alvarez-Torrellas, S.; Casas, J.A.; Rodriguez, J.J. Application of CWPO to the treatment of pharmaceutical emerging pollutants in different water matrices with a ferromagnetic catalyst. J. Hazard. Mater. 2017, 331, 45-54. [CrossRef] [PubMed]

27. Luo, Y.; Guo, W.; Ngo, H.H.; Nghiem, L.D.; Hai, F.I.; Zhang, J.; Liang, S.; Wang, X.C. A review on the occurrence of micropollutants in the aquatic environment and their fate and removal during wastewater treatment. Sci. Total Environ. 2014, 473, 619-641. [CrossRef] [PubMed]

28. Pignatello, J.J.; Oliveros, E.; MacKay, A. Advanced oxidation processes for organic contaminant destruction based on the Fenton reaction and related chemistry. Crit. Rev. Environ. Sci. Technol. 2006, 36, 1-84. [CrossRef]

29. Mena, I.F.; Diaz, E.; Moreno-Andrade, I.; Rodriguez, J.J;; Mohedano, A.F. Stability of carbon-supported iron catalysts for catalytic wet peroxide oxidation of ionic liquids. J. Environ. Chem. Eng. 2018, 6, 6444-6450. [CrossRef]

30. Bedia, J.; Monsalvo, V.M.; Rodriguez, J.J.; Mohedano, A.F. Iron catalysts by chemical activation of sewage sludge with $\mathrm{FeCl} 3$ for CWPO. Chem. Eng. J. 2017, 318, 224-230. [CrossRef]

31. Gosu, V.; Sikarwar, P.; Subbaramaiah, V. Mineralisation of pyridine by CWPO process using nFe0/GAC catalyst. J. Environ. Chem. Eng. 2018, 6, 1000-1007. [CrossRef]

32. Mohedano, A.F.; Monsalvo, V.M.; Bedia, J.; Lopez, J.; Rodriguez, J.J. Highly stable iron catalysts from sewage sludge for CWPO. J. Environ. Chem. Eng. 2014, 2, 2359-2364. [CrossRef]

33. Wang, N.; Zheng, T.; Zhang, G.; Wang, P. A review on Fenton-like processes for organic wastewater treatment. J. Environ. Chem. Eng. 2016, 4, 762-787. [CrossRef]

34. Rizzo, L. Bioassays as a tool for evaluating advanced oxidation processes in water and wastewater treatment. Water Res. 2011, 45, 4311-4340. [CrossRef]

35. Blanco-Galvez, J.; Fernández-Ibáñez, P.; Malato-Rodríguez, S. Solar Photocatalytic Detoxification and Disinfection of Water: Recent Overview. J. Sol. Energy Eng. 2006, 129, 4-15. [CrossRef]

36. He, J.; Yang, X.; Men, B.; Wang, D. Interfacial mechanisms of heterogeneous Fenton reactions catalyzed by iron-based materials: A review. J. Environ. Sci. 2016, 39, 97-109. [CrossRef] [PubMed]

37. Rey, A.; Zazo, J.; Casas, J.; Bahamonde, A.; Rodriguez, J. Influence of the structural and surface characteristics of activated carbon on the catalytic decomposition of hydrogen peroxide. Appl. Catal. A Gen. 2011, 402, 146-155. [CrossRef]

38. Hou, L.; Zhang, Q.; Jérôme, F.; Duprez, D.; Zhang, H.; Royer, S. Shape-controlled nanostructured magnetite-type materials as highly efficient Fenton catalysts. Appl. Catal. B Environ. 2014, 144, 739-749. [CrossRef]

39. Santos, V.P.; Pereira, M.F.; Faria, P.; Órfão, J.J. Decolourisation of dye solutions by oxidation with $\mathrm{H}_{2} \mathrm{O}_{2}$ in the presence of modified activated carbons. J. Hazard. Mater. 2009, 162, 736-742. [CrossRef] [PubMed]

40. Huang, H.; Lu, M.; Chen, J.; Lee, C. Catalytic decomposition of hydrogen peroxide and 4-chlorophenol in the presence of modified activated carbons. Chemosphere 2003, 51, 935-943. [CrossRef]

41. Lücking, F.; Köser, H.; Jank, M.; Ritter, A. Iron powder, graphite and activated carbon as catalysts for the oxidation of 4-chlorophenol with hydrogen peroxide in aqueous solution. Water Res. 1998, 32, 2607-2614. [CrossRef]

42. Rueda-Márquez, J.J.; Pintado-Herrera, M.G.; Martín-Díaz, M.L.; Acevedo-Merino, A.; Manzano, M.A. Combined AOPs for potential wastewater reuse or safe discharge based on multi-barrier treatment (microfiltration- $\mathrm{H}_{2} \mathrm{O}_{2}$ /UV-catalytic wet peroxide oxidation). Chem. Eng. J. 2015, 270, 80-90. [CrossRef]

43. Rueda-Márquez, J.J.; Sillanpää, M.; Pocostales, P.; Acevedo, A.; Manzano, M.A. Post-treatment of biologically treated wastewater containing organic contaminants using a sequence of $\mathrm{H}_{2} \mathrm{O}_{2}$ based advanced oxidation processes: Photolysis and catalytic wet oxidation. Water Res. 2015, 71, 85-96. [CrossRef]

44. Georgi, A.; Kopinke, F. Interaction of adsorption and catalytic reactions in water decontamination processes: Part Oxidation of organic contaminants with hydrogen peroxide catalyzed by activated carbon. Appl. Catal. B Environ. 2005, 58, 9-18. [CrossRef] 
45. Anfruns, A.; Montes-Morán, M.A.; Gonzalez-Olmos, R.; Martin, M.J. $\mathrm{H}_{2} \mathrm{O}_{2}$-based oxidation processes for the regeneration of activated carbons saturated with volatile organic compounds of different polarity. Chemosphere 2013, 91, 48-54. [CrossRef]

46. Ribeiro, R.S.; Silva, A.M.T.; Figueiredo, J.L.; Faria, J.L.; Gomes, H.T. The influence of structure and surface chemistry of carbon materials on the decomposition of hydrogen peroxide. Carbon 2013, 62, 97-108. [CrossRef]

47. Azabou, S.; Najjar, W.; Bouaziz, M.; Ghorbel, A.; Sayadi, S. A compact process for the treatment of olive mill wastewater by combining wet hydrogen peroxide catalytic oxidation and biological techniques. J. Hazard. Mater. 2010, 183, 62-69. [CrossRef] [PubMed]

48. Molina, C.B.; Zazo, J.A.; Casas, J.A.; Rodriguez, J.J. CWPO of 4-CP and industrial wastewater with Al-Fe pillared clays. Water Sci. Technol. 2010, 61, 2161-2168. [CrossRef] [PubMed]

49. Melero, J.A.; Martínez, F.; Botas, J.A.; Molina, R.; Pariente, M.I. Heterogeneous catalytic wet peroxide oxidation systems for the treatment of an industrial pharmaceutical wastewater. Water Res. 2009, 43, 4010-4018. [CrossRef] [PubMed]

50. De Rosa, S.; Giordano, G.; Granato, T.; Katovic, A.; Siciliano, A.; Tripicchio, F. Chemical pretreatment of olive oil mill wastewater using a metal-organic framework catalyst. J. Agric. Food Chem. 2005, 53, 8306-8309. [CrossRef] [PubMed]

51. Pariente, M.; Melero, J.; Martínez, F.; Botas, J.; Gallego, A. Catalytic wet hydrogen peroxide oxidation of a petrochemical wastewater. Water Sci. Technol. 2010, 61, 1829-1836. [CrossRef] [PubMed]

52. Bautista, P.; Mohedano, A.; Casas, J.; Zazo, J.; Rodriguez, J. Oxidation of cosmetic wastewaters with $\mathrm{H}_{2} \mathrm{O}_{2}$ using a Fe $/ \gamma$-Al2O3 catalyst. Water Sci. Technol. 2010, 61, 1631-1636. [CrossRef] [PubMed]

53. Fang, Y.; Yin, W.; Jiang, Y.; Ge, H.; Li, P.; Wu, J. Depth treatment of coal-chemical engineering wastewater by a cost-effective sequential heterogeneous Fenton and biodegradation process. Environ. Sci. Pollut. Res. 2018, 25, 13118-13126. [CrossRef] [PubMed]

54. Domínguez, C.M.; Quintanilla, A.; Casas, J.A.; Rodriguez, J.J. Treatment of real winery wastewater by wet oxidation at mild temperature. Sep. Purif. Technol. 2014, 129, 121-128. [CrossRef]

55. Martínez, F.; Melero, J.A.; Botas, J.Á.; Pariente, M.I.; Molina, R. Treatment of phenolic effluents by catalytic wet hydrogen peroxide oxidation over Fe2O3/SBA-15 extruded catalyst in a fixed-bed reactor. Ind. Eng. Chem. Res. 2007, 46, 4396-440557. [CrossRef]

56. Zazo, J.A.; Casas, J.A.; Mohedano, A.F.; Rodríguez, J.J. Catalytic wet peroxide oxidation of phenol with a Fe/active carbon catalyst. Appl. Catal. B Environ. 2006, 65, 261-268. [CrossRef]

57. Qin, H.; Xiao, R.; Shi, W.; Wang, Y.; Li, H.; Guo, L.; Cheng, H.; Chen, J. Magnetic core-shell-structured Fe3O4@ CeO2 as an efficient catalyst for catalytic wet peroxide oxidation of benzoic acid. RSC Adv. 2018, 8, 33972-33979. [CrossRef]

58. Du, W.; Xu, Y.; Wang, Y. Photoinduced degradation of orange II on different iron (hydr) oxides in aqueous suspension: Rate enhancement on addition of hydrogen peroxide, silver nitrate, and sodium fluoride. Langmuir 2008, 24, 175-181. [CrossRef] [PubMed]

59. Pliego, G.; Zazo, J.A.; Blasco, S.; Casas, J.A.; Rodriguez, J.J. Treatment of highly polluted hazardous industrial wastewaters by combined coagulation-adsorption and high-temperature Fenton oxidation. Ind. Eng. Chem. Res. 2012, 51, 2888-2896. [CrossRef]

60. Chou, S.; Huang, C. Application of a supported iron oxyhydroxide catalyst in oxidation of benzoic acid by hydrogen peroxide. Chemosphere 1999, 38, 2719-2731. [CrossRef]

61. Prasad, J.; Tardio, J.; Jani, H.; Bhargava, S.K.; Akolekar, D.B.; Grocott, S.C. Wet peroxide oxidation and catalytic wet oxidation of stripped sour water produced during oil shale refining. J. Hazard. Mater. 2007, 146, 589-594. [CrossRef] [PubMed]

62. Sánchez Pérez, J.A.; Román Sánchez, I.M.; Carra, I.; Cabrera Reina, A.; Casas López, J.L.; Malato, S. Economic evaluation of a combined photo-Fenton/MBR process using pesticides as model pollutant. Factors affecting costs. J. Hazard. Mater. 2013, 244, 195-203. [CrossRef]

63. Miralles-Cuevas, S.; Oller, I.; Agüera, A.; Sánchez Pérez, J.A.; Malato, S. Strategies for reducing cost by using solar photo-Fenton treatment combined with nanofiltration to remove microcontaminants in real municipal effluents: Toxicity and economic assessment. Chem. Eng. J. 2017, 318, 161-170. [CrossRef]

64. García, E.B.; Rivas, G.; Arzate, S.; Sánchez Pérez, J.A. Wild bacteria inactivation in WWTP secondary effluents by solar photo-fenton at neutral $\mathrm{pH}$ in raceway pond reactors. Catal. Today 2017, 313, 72-78. [CrossRef] 
65. Sanabria, N.R.; Peralta, Y.M.; Montañez, M.K.; Rodríguez-Valencia, N.; Molina, R.; Moreno, S. Catalytic oxidation with Al-Ce-Fe-PILC as a post-treatment system for coffee wet processing wastewater. Water Sci. Technol. 2012, 66, 1663-1668. [CrossRef]

66. Rueda-Márquez, J.J.; Levchuk, I.; Uski, J.; Sillanpää, M.; Acevedo, A.; Manzano, M.A. Post-treatment of plywood mill effluent by Multi-Barrier Treatment: A pilot-scale study. Chem. Eng. J. 2016, 283, 21-28. [CrossRef]

67. Rueda-Márquez, J.J.; Levchuk, I.; Salcedo, I.; Acevedo-Merino, A.; Manzano, M.A. Post-treatment of refinery wastewater effluent using a combination of AOPs $\left(\mathrm{H}_{2} \mathrm{O}_{2}\right.$ photolysis and catalytic wet peroxide oxidation) for possible water reuse. Comparison of low and medium pressure lamp performance. Water Res. 2016, 91, 86-96.

68. Drábková, M.; Matthijs, H.; Admiraal, W.; Maršálek, B. Selective effects of $\mathrm{H}_{2} \mathrm{O}_{2}$ on cyanobacterial photosynthesis. Photosynthetica 2007, 45, 363-369. [CrossRef]

69. St. Laurent, J.B.; de Buzzaccarini, F.; De Clerck, K.; Demeyere, H.; Labeque, R.; Lodewick, R.; van Langenhove, L. Laundry Cleaning of Textiles; Elsevier: Amsterdam, The Netherlands, 2007; pp. 57-102.

70. U.S. Department of the Interior Bureau of Reclamation. Reverse Osmosis Treatment of Central Arizona Project Water for the City of Tucson. Desalination Research and Development Program Report No. 36, Costs 20 Appendix C. 2004. Available online: https://www.usbr.gov/research/dwpr/reportpdfs/report036.pdf (accessed on 2 October 2018).

71. Nguyen, T.V.; Jeong, S.; Pham, T.T.N.; Kandasamy, J.; Vigneswaran, S. Effect of granular activated carbon filter on the subsequent flocculation in seawater treatment. Desalination 2014, 354, 9-16. [CrossRef]

72. Domínguez, C.M.; Ocón, P.; Quintanilla, A.; Casas, J.A.; Rodriguez, J.J. Highly efficient application of activated carbon as catalyst for wet peroxide oxidation. Appl. Catal. B Environ. 2013, 140, 663-670. [CrossRef]

73. Munoz, M.; Garcia-Muñoz, P.; Pliego, G.; Pedro, Z.M.D.; Zazo, J.A.; Casas, J.A.; Rodriguez, J.J. Application of intensified Fenton oxidation to the treatment of hospital wastewater: Kinetics, ecotoxicity and disinfection. J. Environ. Chem. Eng. 2016, 4, 4107-4112. [CrossRef]

74. Pliego, G.; Zazo, J.A.; Garcia-Muñoz, P.; Munoz, M.; Casas, J.A.; Rodriguez, J.J. Trends in the intensification of the Fenton process for wastewater treatment: An overview. Crit. Rev. Environ. Sci. Technol. 2015, 45, 2611-2692. [CrossRef]

75. Bergault, I.; Rajashekharam, M.; Chaudhari, R.; Schweich, D.; Delmas, H. Modeling and comparison of acetophenone hydrogenation in trickle-bed and slurry airlift reactors. Chem. Eng. Sci. 1997, 52, 4033-4043. [CrossRef]

(C) 2018 by the authors. Licensee MDPI, Basel, Switzerland. This article is an open access article distributed under the terms and conditions of the Creative Commons Attribution (CC BY) license (http:/ / creativecommons.org/licenses/by/4.0/). 